11 Smith HT, Shapiro FL, Messner RP. Anuria secondary to renovascular disease. F $A M A$ 1968;204:928-30.

12 Sheil AGR, May J, Stokes GS, Johnson JR, Tiller DJ, Stewart JH. Reversal of renal failure by revascularisation of kidneys with thrombosed renal arteries. Lancet 1973 ;ii:865-6.

${ }^{13}$ Morgan T, Wilson M, Johnston W, Clunie GJ, Gordon R. Restoration of renal function by arterial surgery. Lancet $1974 ; \mathrm{i}: 653-6$.

${ }^{14}$ Mackay A. Recovery of renal function after renovascular surgery. Scott Med F (in press).

${ }^{15}$ Perkins RP, Jacobsen DS, Feder FP, Lipchik EO, Fine PH. Return of renal function after late embolectomy. $N$ Engl f Med 1967;276:1194-5.
${ }^{16}$ Morris GCJ, Heider C, Moyer JH. The protective effect of subfiltration arterial pressure on the kidney. Surg Forum 1955;6:623-7.

17 O'Conor VJ. Renal artery stenosis and azotaemia. Trans Am Assoc Genitourin Surg 1973;65:17.

18 Grüntzig A, Kuhlmann U, Vetter W, Lütolf V, Meier B, Siegenthaler W. Treatment of renovascular hypertension with percutaneous transluminal dilatation of a renal artery stenosis. Lancet $1978 ; \mathrm{i}: 801-2$.

19 Katzen BT, Chang J, Lukowsky GH, Abramson EG. Percutaneous transluminal angioplasty for treatment of renovascular hypertension. Radiology 1979;131:53-8.

\title{
Generalised tissue abnormality of aryl hydrocarbon hydroxylase in psoriasis
}

\author{
P H CHAPMAN，P J KERSEY， BARBARA KEYS， SAM SHUSTER，M D RAWLINS
}

\section{Summary and conclusions}

Microsomal aryl hydrocarbon hydroxylase (AHH) activity and inducibility were measured in jejunal mucosa, liver, and lesion-free epidermis of patients with psoriasis. In all three tissues AHH activity and inducibility were less than in controls.

This demonstration of a generalised enzymatic abnormality in the tissues of patients with psoriasis is in keeping with the suggestion that it may be close to the underlying genetic defect.

\section{Introduction}

We have recently reported that the activity of epidermal aryl hydrocarbon hydroxylase ( $\mathrm{AHH}, \mathrm{EC} 1.1414 .2)$ is reduced in the untreated, clinically normal, lesion-free skin of patients with chronic discoid ${ }^{1}$ and palmar-plantar pustular psoriasis. ${ }^{2}$ Moreover, in-vitro induction of $\mathrm{AHH}$ by incubation with benzanthracene was less than in skin from people without psoriasis. Because this abnormality appears to be unique to psoriasis $^{3}$ and because it affects skin which has never been affected by the lesions of psoriasis ${ }^{2}$ we have suggested that it may be related to the underlying genetic defect of the disease. ${ }^{2}{ }^{4}$ If this suggestion is correct it might be expected that a similar defect would also occur in tissues other than skin. We therefore measured microsomal AHH activity in the jejunal mucosa and liver of patients with psoriasis.

\section{Patients and methods}

Epidermal biopsy-Epidermal biopsy specimens were obtained by suction blisters from 43 patients (aged 18-73) with chronic psoriasis. Four of these also underwent liver or jejunal biopsy, or both. There were 73 biopsy specimens from control subjects of comparable age but without psoriasis.

\footnotetext{
Department of Dermatology, Newcastle University, Newcastle upon Tyne NE1 4LP

P J KERSEY, MRCP, senior registrar

SAM SHUSTER, PHD, FRCP, professor

Department of Clinical Pharmacology, Wolfson Unit, Newcastle University, Newcastle upon Tyne NE1 7RU

P H CHAPMAN, PHD, Janssen lecturer

BARBARA KEYS, research technician

M D RAWLINS, MD, FRCP, professor
}

fejunal biopsy-Eight patients (four men) with chronic discoid psoriasis (aged 19-58 years) affecting $10-30 \%$ of their body surface and 11 patients (five men; aged $46 \pm$ SE 5 years) with disorders unassociated with abnormal epidermal $\mathrm{AHH}$ activity (eczema, 4 patients; parapsoriasis, 1 ; geographic tongue, 1 ; polyarthropathy, 1 ; Gorlin's syndrome, 1 ; erythema elevatum diutinum, 1 ; normal, 2) underwent jejunal biopsy with a modified Crosby capsule under fluoroscopic control. No patient had received any systemic or topical drug treatment during the three weeks before biopsy. Fully informed consent was obtained from all patients undergoing jejunal and epidermal biopsies.

Hepatic biopsy-Liver tissue was obtained from 13 patients undergoing percutaneous (Menghini needle) biopsy for diagnostic purposes, when it was surplus to that required for histology. Six patients (all men; aged 41-71 years) had chronic discoid psoriasis and were undergoing assessment for methotrexate treatment; five patients (all men; aged 27-72 years) with parapsoriasis and mycosis fungoides were undergoing investigation for systemic reticulosis. None of these patients had clinical or biochemical evidence of liver disease (serum bilirubin, aspartate transaminase, alkaline phosphatase, albumin), none were taking drugs at the time of study, and all had normal liver histological findings. In addition liver was studied from two patients in whom cirrhosis was suspected: in one the liver was found to be normal and the other had minimal cirrhosis.

Measurement of AHH activity-Biopsy samples were immediately placed in ice-cold TRIS buffer ( $\mathrm{pH} 7 \cdot 4)$ and transferred to the laboratory, where the specimen was divided into two parts and weighed. Both portions were incubated in a tissue culture system for 18 hours at $37^{\circ} \mathrm{C}$ in an atmosphere of $95 \% \mathrm{O}_{2}: 5 \% \mathrm{CO}_{2}{ }^{5}$; one portion was incubated in medium containing benzanthracene $(100 \mu \mathrm{g} / \mathrm{mol} / \mathrm{l})$. Microsomal AHH activity was measured using benz(a)pyrene as substrate, and expressed as pmol 3-hydroxybenzpyrene formed/mg microsomal protein/hour (pmol 3-OH BP/mg protein/h). "Basal" and "induced" AHH activities were calculated from results obtained after incubation without and with benzanthracene. The induction ratio was calculated from the ratio of induced to basal AHH activities. ${ }^{1}$

\section{Results}

The results (see table) were the same for all three tissues and showed that basal AHH activity in psoriatics was significantly less than in the controls. After induction by preincubation with benzanthracene, AHH activity was similarly less in psoriatics than in the controls; thus, the induction ratio was less than normal in all three tissues from psoriatic patients.

\section{Discussion}

These results confirm our previous observations ${ }^{12}$ that $\mathrm{AHH}$ activity and inducibility is reduced in the clinically normal skin 
Mean ( $\pm S E$ ) aryl hydrocarbon hydroxylase activity (pmol 3-OH BP/mg protein/h) in epidermis, jejunum, and liver

\begin{tabular}{|c|c|c|c|c|c|c|c|c|c|}
\hline & & \multicolumn{4}{|c|}{ Controls } & \multicolumn{4}{|c|}{ Patients with Psoriasis } \\
\hline & & $\begin{array}{c}\text { No of } \\
\text { patients }\end{array}$ & $\begin{array}{l}\text { Basal } \\
\text { AHH }\end{array}$ & $\begin{array}{l}\text { Induced } \\
\mathrm{AHH}\end{array}$ & $\begin{array}{l}\text { Induction } \\
\text { ratio }\end{array}$ & $\begin{array}{c}\text { No of } \\
\text { patients }\end{array}$ & $\begin{array}{l}\text { Basal } \\
\text { AHH }\end{array}$ & $\begin{array}{l}\text { Induced } \\
\mathrm{AHH}\end{array}$ & $\begin{array}{c}\text { Induction } \\
\text { ratio }\end{array}$ \\
\hline $\begin{array}{l}\text { Epidermis } \\
\text { Jejunal mucosa } \\
\text { Liver } \ldots\end{array}$ & $\because$ & $\begin{array}{r}79 \\
11 \\
7\end{array}$ & $\begin{array}{l}3 \cdot 92 \pm \cdot 23 \\
74 \cdot 4 \pm 7 \cdot 4 \\
63 \cdot 4 \pm 12 \cdot 9\end{array}$ & $\begin{array}{c}8 \cdot 46 \pm 52^{*} \\
154 \cdot 4 \pm 13 \cdot 5^{*} \\
134 \cdot 1 \pm 22 \cdot 7^{*}\end{array}$ & $\begin{array}{l}2 \cdot 16 \pm \cdot 12 \\
2 \cdot 18 \pm \cdot 23 \\
2 \cdot 23 \pm \cdot 17\end{array}$ & $\begin{array}{r}43 \\
8 \\
6\end{array}$ & $\begin{array}{l}2 \cdot 50 \pm 16 \dagger \\
22 \cdot 3 \pm 1 \cdot 3 \dagger \\
36 \cdot 6 \pm 2 \cdot 9\end{array}$ & $\begin{array}{l}3 \cdot 33 \pm \cdot 29+ \\
24 \cdot 3 \pm 2 \cdot 1 \ddagger \\
40 \cdot 0 \pm 2 \cdot 7 \ddagger\end{array}$ & $\begin{array}{l}1 \cdot 33 \pm \cdot 10 \S \\
1 \cdot 09 \pm 06 \S \\
1 \cdot 10 \pm \cdot 03 \S\end{array}$ \\
\hline
\end{tabular}

* Significant difference $(\mathrm{p}<0.001)$ between basal and inducted AHH activity.

†Significant difference $(\mathrm{p}<0.001)$ between control and psoriatic basal AHH activity

$\ddagger$ Significant difference $(\mathrm{p}<0.001)$ between control and psoriatic induced AHH activity but similar $(\mathrm{p}>0 \cdot 2)$ activity to psoriatic basal AHH.

$\S$ Significant difference $(\mathrm{p}<0.001)$ between control and psoriatic induction ratio.

of patients with psoriasis. More importantly, they show that this abnormality is also present in the jejunal mucosa and liver of these patients. Furthermore, the results were concordant in the psoriatic individuals in whom $\mathrm{AHH}$ activity was measured in more than one tissue. Minor defects of small bowel and liver structure and function have been described in psoriasis ${ }^{6}$ ? but they mostly occur in patients with extensive skin disease. They are also observed in patients with other widespread dermatoses, ${ }^{6}{ }^{7}$ in whom impaired epidermal $\mathrm{AHH}$ activity and inducibility does not occur. ${ }^{3}$ Thus the defect of AHH activity and inducibility which appears to be specific to patients with psoriasis is also widespread in their clinically unaffected tissues. This is the first demonstration of a generalised enzyme defect in psoriasis and is in keeping with our suggestion that it may be close to the underlying genetic defect.

Microsomal mono-oxygenases, of which $\mathrm{AHH}$ forms part, have a role in the metabolism of a wide variety of foreign compounds, drugs, and carcinogens. We have recently shown that while the systemic clearance of antipyrine is decreased in patients with psoriasis the 4-hydroxylation of debrisoquine is not (unpublished observations). The oxidation of these two compounds is mediated by different forms of the cytochromes concerned in microsomal mono-oxygenase activity. Therefore the widespread tissue abnormality of $\mathrm{AHH}$ in psoriasis probably represents a defect of a specific part of the mono-oxygenase system.

The demonstration of a generalised and specific enzyme defect in the tissues of patients with psoriasis has both theoretical and practical implications. Firstly, it should help to clarify the relation between certain systemic and cutaneous disorders and psoriasis and resolve the dispute about its genetic transmission. Secondly, it may provide a better understanding of the development of the rash; we have already shown that cellophane tape stripping induces a decrease in epidermal $\mathrm{AHH}$ activity $^{8}$ and a rapid turnover of epidermis such as occurs in the lesions. Thirdly, since AHH converts many environmental chemicals to carcinogenic metabolites, it supports our hypothesis ${ }^{4}$ that psoriasis may protect against malignant change in a wide variety of tissues including skin. Finally, our findings indicate that the cutaneous and systemic metabolism of some drugs may be changed in psoriasis (unpublished observations), with alterations in their efficacy and toxicity.

Since this work was completed Ruzicka et $a^{9}$ have reported that lymphocyte $\mathrm{AHH}$ activity is normal in patients with psoriasis. While lymphocyte AHH activity may be under different control from that in other tissues, the difference is more likely to be due to the poor reliability and reproducibility of measurement of lymphocyte $\mathrm{AHH}$ and the inclusion of large numbers of cigarette smokers. Thus we have shown that the impaired systemic metabolism of antipyrine in psoriasis (nonsmoking psoriatics $v$ non-smoking controls) is masked by monooxidase induction in psoriatics patients who smoke (unpublished observations).

This work was supported by a Medical Research Council programme grant.

\section{References}

${ }^{1}$ Chapman PH, Rawlins MD, Shuster S. The activity of aryl hydrocarbon hydroxylase in psoriatic skin. Lancet $1979 ; \mathrm{i}: 297-8$.

2 Shuster S, Rawlins MD, Chapman PH, Rogers S. Decreased epidermal AHH and localised pustular psoriasis. Br $\mathcal{F}$ Dermatol 1980;103:23-6.

${ }^{3}$ Kersey P, Chapman PH, Shuster S, Rawlins MP. Activity of AHH in skin disease. Scott Med f (in press).

4 Shuster S, Chapman PH, Rawlins MD. Psoriasis and cancer. Br Med $\mathcal{F}$ $1979 ; \mathrm{i}: 941-2$.

${ }^{5}$ Chapman PH, Rawlins MD, Shuster S. The activity of aryl hydrocarbon hydroxylase in adult human skin. Br f Clin Pharmacol 1979;7:499-503.

${ }^{6}$ Shuster S, Marks JM. Systemic effects of skin disease. London:Heineman, 1970:52, 82 .

7 Shuster S, Marks JM. Dermatogenic enteropathy, a new cause of steatorrhoea. Lancet $1965 ; \mathrm{i}: 1367$.

${ }^{8}$ Chapman PH, Rawlins MD, Shuster S, Rogers S. Impaired epidermal microsomal AHH activity in discoid and pustular psoriasis. $\mathcal{F}$ Invest Dermatol $1979 ; 72: 267-8$.

${ }^{9}$ Ruzicka T, Vizethum W, Jacobs A, Goerz G. Aryl hydrocarbon hydroxylase activity in lymphocytes of patients with psoriasis. Lancet $1980 ; \mathrm{i}$ : 1142 .

(Accepted 1 October 1980)
ONE HUNDRED YEARS AGO The National Health Society, Berners Street, is calling the attention of the vestries of the Metropolis to the unwholesome condition of the streets of London in hot weather. In a document signed on behalf of the council by Mr Ernest Hart, chairman, and others, it is represented that the intolerable smells that have lately pervaded the streets of the West End have been the subject of frequent complaints in the daily papers. Streets, smelling like very badly kept stable-yards, have been throughout the past and other seasons, injurious to health and prejudicial to trade. It is estimated that more than one thousand loads of dung are daily deposited in the streets of the metropolis, one hundred loads in the streets of the city. Even the surface-cleaning is so imperfect in the greater part of London that much of this filth remains upon the streets in a noxious state of decomposition. while it is blown about by the wind and washed into the drains, where it too often lies stagnant in the ill-constructed and ill-cleansed sewers, which are under the charge of the vestries. In some of the streets under the care of the
Corporation of the City, a more perfect daily sweeping keeps the surface clean; but we must go to Paris, Vienna, or Madrid, to see streets thoroughly well washed and clean. In the City of London, the hydrants which are now in use for protection from fire might well be made serviceable for washing the streets and flushing the sewers. Heavy thunder-showers and storms of rain occasionally act as scavengers, and actually diminish the death-rate by their refreshing effects. Much might be done by amending the form of the sewers, and making them self-cleansing. It is said that where this has been done, in a part of Holborn, the expense has been less than that involved in cleansing them by flushing. No doubt the early attainment of a water-supply, under competent scientific and public control, will be the most effective means of remedying these evils. It cannot, meanwhile, be too often repeated to intelligent ratepayers that all foul depressing smells mean the continuance of sickness and of a high death-rate. (British Medical fournal, 1880.) 